\title{
Evaluation of Granulocyte Elastase Enzyme in Diagnosis of Spontaneous Bacterial Peritonitis
}

\author{
Mohamed Abed El-Aziz Metwally ${ }^{1}$, Mohammad El-Sayed El-Shewi ${ }^{1}$, \\ Jehan Hassan Sabry ${ }^{2}$, Mahmoud M Abed EI Magid ${ }^{3}$ \\ ${ }^{1}$ Hepatology, Gastroenterology and Infectious Diseases Department, Faculty of Medicine, Benha \\ University, Benha, Egypt \\ ${ }^{2}$ Clinical and Chemical Pathology Department, Faculty of Medicine, Benha University, Benha, Egypt \\ ${ }^{3}$ Hepatology, Gastroenterology and Infectious Diseases Department, Shebein El-Kom Fever Hospital, \\ Shebein El-Kom, Egypt
}

Corresponding Author Mahmoud Mohammad Abed El Magid

Mobile:

$+201004818324$

E mail:

drmahmoud2004@ gmail.com

Key words:

Granulocyte elastase, spontaneous bacterial peritonitis, Cirrhosis
Background and study aim: The most common infections in decompensated liver cirrhotic ascites patients are cases of spontaneous bacterial peritonitis (SBP), which account for $40 \%-70 \%$ of cases. SBP is a bacterial infection that occurs in absence of an evident intra-abdominal or surgically treatable source of infection.

Patients and methods: This study was conducted on 80 patients with liver cirrhosis and ascites; 40 patients of them without SBP (group A) and 40 patients of them with SBP (group B) who were admitted to the Hepatology, Gastroenterology and Infectious Diseases Department, Benha University Hospital in the period between April 2014 and October 2014. Full history taking, clinical examination and laboratory investigation were done. Ascitic fluid

\section{INTRODUCTION}

Liver cirrhosis is the clinical endstage of different entities of chronic liver disease when patients suffer from substantial mortality and morbidity, both of which are positively correlated with disease severity [1]. Cirrhosis represents the final common histological pathway for a wide variety of chronic liver diseases. Cirrhosis is defined histologically as a diffuse hepatic process characterized by fibrosis and the conversion of normal liver architecture into structurally abnormal nodules. Some patients with cirrhosis are completely asymptomatic and have a reasonably normal life expectancy. Other individuals have a multitude of the most severe symptoms of endstage liver disease and have a limited chance for survival. Common signs and symptoms may stem from decreased analysis was done including detection of granulocyte elastase level.

Results: Granulocyte elastase was markedly elevated in group B; mean ascitic fluid GE ELISA (4.1 \pm 2.8$)$ comparing with group $\mathrm{A}(0.8 \pm 0.7)$ and it revealed a high statistically significant association between SBP and GE (P value <0.05). SBP was more common in child $\mathrm{C}$. Fever, hypotension and abdominal pain were more common in SBP group.

Conclusion: Granulocyte elastase is increased in cases of SBP, cutoff value of ascitic fluid (GE) for diagnosis of SBP at $0.88 \mathrm{ng} / \mathrm{mL}$ had $100 \%$ sensitivity, $75 \%$ specificity, $80 \%$ positive predictive value, $100 \%$ negative predictive value and $87.5 \%$ accuracy.

hepatic synthetic function, decreased detoxification capabilities of the liver (e.g, hepatic encephalopathy), or portal hypertension (e.g, variceal bleeding) [2].

Ascites is defined as an accumulation of excessive fluid within the peritoneal cavity and may be a complication of both hepatic and non-hepatic diseases. The 4 most common causes of ascites are cirrhosis, neoplasm, congestive heart failure, and tuberculous peritonitis [3].

Spontaneous bacterial peritonitis (SBP) is defined as the infection of ascitic fluid (AF) in the absence of a contiguous source of infection and/or an intra-abdominal inflammatory focus. An ascitic fluid polymorphonuclear (PMN) leucocyte count $\geq 250 / \mathrm{mm}^{3}$ irrespective of the AF culture result is universally accepted nowadays as the 
best surrogate marker for diagnosing SBP. Frequently the results of the manual or automated PMN count do not reach the hands of the responsible medical personnel in a timely manner [4].

Alternative methods using automated PMN counting [5], reagent strips [6], or ascitic fluid lactoferrin [7] have been developed. Unfortunately, their diagnostic accuracies are limited. Therefore, an accurate and convenient method of rapid diagnosis of SBP remains an unmet clinical need [8].

Granulocyte elastase (GE) is a powerful proteolytic enzyme that is released by PMNs when degranulated in infectious processes [9].However more studies are needed to evaluate the accuracy of this test in diagnosis of SBP.

\section{PATIENTS AND METHODS}

\section{Study design:}

Cross-sectional study.

\section{Patients:}

We enrolled in the study 80 patients with decompensated chronic liver disease and ascites 40 patients of them without SBP (group A) and 40 patients of them with SBP (group B) who were admitted to the Hepatology, Gastroenterology and Infectious Diseases Department, Benha University Hospital in the period between April 2014 and October 2014 after approval of ethical committee of Benha Faculty of Medicine. The study was performed after written informed consent from all patients.

Fulfilling all criteria detailed below.

\section{Inclusion criteria:}

Ascitic patients with clinical, laboratory and ultrasongraphic findings of liver cirrhosis were included when:

1. Age $>18$ years.

2. Symptoms and signs suggest SBP as fever and abdominal pain.

\section{Exclusion criteria:}

Patients were excluded when they had any of the following criteria:

1. Patients with antibiotic therapy within one month before.

2. Recent abdominal surgery ( $<3$ months).

3. Abdominal malignancy as HCC and Colorectal carcinoma.
4. Secondary peritonitis due to intra-abdominal infection for example: abscess, appendicitis, cholecystitis and pancreatitis.

5. Other comorbidities e.g chronic obstructive pulmonary disease, chronic renal failure and ischemic heart disease.

\section{Clinical and Laboratory Assessment:}

All patients were subjected to the following: Thorough history taking, through clinical examination, ultrasonographic evaluation and routine laboratory investigations including blood picture, liver and kidney function tests, viral markers.

\section{Sampling:}

1. Five $\mathrm{ml}$ blood was withdrawn by venipuncture, one $\mathrm{ml}$ in EDTA tube for CBC and four ml delivered into plastic tube and allowed to clot. Non-hemolyzed sera was separated by centrifugation and used for determination of creatinine, urea and liver functions (ALT, AST, total bilirubin, albumin, PT and INR).

2. Ascitic fluid sample was taken by paracentesis performed under aseptic conditions from a puncture site in the left or right lower quadrant with the patient in the supine position. All samples for diagnostic testing were immediately collected at the bedside and processed by laboratory personnel without further delay.

\section{Methodology:}

1- Complete blood picture using (Sysmax 5, Chuo-ku, Kobe, Japan) [10].

2- Renal function test: blood urea and serum creatinine were determined calorimetrically on Dialab auto analyzer [11].

3- Liver function tests were determined calorimetrically on Dialab auto analyzer and include the following:

- Serum alanine transaminase (ALT).

- Serum aspartate transaminase (AST).

- Serum bilirubin (Total and direct).

- Serum albumin.

- Prothrombin time and INR were done using coagulometer [12].

4- Serological tests for viral markers using:

A. HBs Ag was determined using non competitive sandwich assay on (ELISA) based technique [13].

B. HCV Antibodies were detected using a third generation enzyme linked immunosorbent assay (ELISA) technique [14]. 
5- Ascitic fluid examination for total protein content, albumin, glucose, Lactate dehydrogynase (LDH) and total and differential WBCs counting.

6- Ascitic fluid granulocyte elastase was measured by an enzyme-linked immunosorbent assay specific for human granulocyte elastase by a laboratory blinded to the patients' clinical information and other laboratory results. The kit was supplied from Sunred-bio, Shanghai, China.

\section{Statistical analysis:}

Statistical presentation and analysis of the present study was conducted SPSS V.20. Data was expressed into two phases:

I Descriptive 1- Mean value (X) and Standard Deviation [SD]: for quantitative data. 2Frequency and percentage for qualitative data.

II Analytic by t-student test and Chi-square test. $P$ value $>0.05$ was considered statistically non significant $\mathrm{P}$ value $\leq 0.05$ was considered statistically significant. $\mathrm{P}$ value $\leq 0.001$ was considered statistically highly significant.

\section{RESULTS}

Sixty one of them $(76.3 \%)$ were males and nineteen $(23.7 \%)$ were females (Table 1$)$.

By comparison between group A and group B regarding demographic data, there was no statistical significant difference regarding gender, age or residence ( $\mathrm{P}$ value $>0.05$ ) (Table 2 ).

Seventy seven patients (96.3\%) of studied patients were $\mathrm{HCV}$ Ab positive and three patients (3.7\%) were HBsAg positive and no patient has coinfection (Table 3).

By comparison between group A and group B regarding clinical presentation; abdominal pain and vomiting were founded in $55 \%$ and $25 \%$ of studied patients in group A. While in group B they had founded in $75 \%$ and $45 \%$ without statically significant difference $(\mathrm{P}$ value $>0.05)$ (Table 4).

Jaundice, disorientation and flapping tremor were present in $60 \%, 52.5 \%$ and $50 \%$ respectively in group A. While they were present in $65 \%, 75 \%$ and $42.5 \%$ respectively in group B without statistical significant difference between both groups ( $\mathrm{P}$ value $>0.05$ ). There was statistical significant difference between both groups regarding systolic blood pressure and temperature (Table 5).

By comparison between group A and group B regarding initial laboratory data. There was no statistical significant difference between both groups ( $\mathrm{P}$ value $>0.05$ ) (Table 6).

By comparison between group A and group B regarding ascitic fluid protein, glucose and LDG, there was no statistical significant difference ( $\mathrm{P}$ value > 0.05) (Table7).

By comparison between group A and group B regarding ascitic fluid granulocyte elastase. There was high statistically significant difference between both groups regarding granulocyte elastase $(\mathrm{P}$ value $<0.05)$ (Table 8$)$.

SBP was more common in Child Turcotte Pugh Score class C $(87,5 \%)$, while $65 \%$ of patients with sterile ascites are Child Turcotte Pugh Score class C (Table 9).

There was a highly statistical significant difference regarding TLC and PMN count in ascitic fluid of SBP group compared to non SBP group (Table 10).

There was a highly statistical significant difference regarding PMN count in ascitic fluid, ascitic fluid (GE) test of SBP group compared to non SBP group (Table 11).

A cutoff value of ascitic fluid (GE) for diagnosis of SBP at $0.88 \mathrm{ng} / \mathrm{mL}$ had $100 \%$ sensitivity, $75 \%$ specificity, $80 \%$ positive predictive value, $100 \%$ negative predictive value and had $87.5 \%$ accuracy (Figure 1).

Table (1): Demographic description of studied patients

\begin{tabular}{|l|c|c|}
\hline \multicolumn{1}{|c|}{ Variable } & Number (80) & \% \\
\hline Gender: & & \\
Male & 61 & $76.3 \%$ \\
Female & 19 & $23.7 \%$ \\
\hline
\end{tabular}


Table (2): Comparison between group A (Non SBP) and group B (SBP) regarding demographic features

\begin{tabular}{|l|c|c|c|}
\hline Variable & $\begin{array}{c}\text { Group A } \\
\text { Non SBP } \\
(\mathbf{N = 4 0 )}\end{array}$ & $\begin{array}{c}\text { Group B } \\
\text { SBP } \\
(\mathbf{N = 4 0 )}\end{array}$ & P. Value \\
\hline Female & $13(32.5 \%)$ & $6(15 \%)$ & 0.07 \\
Male & $27(67.5 \%)$ & $34(85 \%)$ & 0.07 \\
\hline Rural & $27(67.5 \%)$ & $34(85 \%)$ & 0.2 \\
Urban & $13(32.5 \%)$ & $6(15 \%)$ & \\
\hline Age & $58.3 \pm 8.3$ & $55.8 \pm 7.5$ & 0.5 \\
\hline
\end{tabular}

Table (3): Etiology of the chronic liver disease in studied patients. (Virological markers)

\begin{tabular}{|c|c|c|}
\hline Variable & Number (80) & \% \\
\hline $\mathrm{HCV} \mathrm{Ab}(+\mathrm{ve})$ & 77 & $96.25 \%$ \\
\hline $\mathrm{HBS} \mathrm{Ag}(+\mathrm{ve})$ & 3 & $3.75 \%$ \\
\hline
\end{tabular}

Table (4): Comparison between group A (Non SBP) and group $\mathrm{B}(\mathrm{SBP})$ regarding clinical presentations

\begin{tabular}{|l|c|c|c|}
\hline \multicolumn{1}{|c|}{ Variable } & $\begin{array}{c}\text { Group A } \\
\text { Non SBP } \\
(\mathbf{N = 4 0 )}\end{array}$ & $\begin{array}{c}\text { Group B } \\
\text { SBP } \\
(\mathbf{N = 4 0 )}\end{array}$ & P. Value \\
\hline Main Complain: & $19(47.5 \%)$ & $23(57.5 \%)$ & 0.4 \\
1-Abdominal pain & $9(22.5 \%)$ & $4(10 \%)$ & 0.1 \\
2-Marked abdominal enlargement & $11(27.5 \%)$ & $13(32.5 \%)$ & 0.6 \\
3-Fever & 0 & $3(7.5 \%)$ & 0.08 \\
5-Vomiting & $7(17.5 \%)$ & $4(10 \%)$ & 0.3 \\
6-Hematemesis & & & \\
\hline Symptoms & $22(55 \%)$ & $30(75 \%)$ & 0.06 \\
1-Abdominal pain & $10(25 \%)$ & $18(45 \%)$ & 0.06 \\
2-Vomiting & $4(10 \%)$ & $8(20 \%)$ & 0.2 \\
3-Diarrhea & $6(15 \%)$ & $6(15 \%)$ & 1 \\
4-Hematemesis & $6(15 \%)$ & $6(15 \%)$ & 0.5 \\
5-Melena & \multicolumn{2}{|l}{} \\
\hline
\end{tabular}


Table (5): Comparison between group A (Non SBP) and group B (SBP) regarding clinical examinations

\begin{tabular}{|l|c|c|c|}
\hline \multicolumn{1}{|c|}{ Variable } & $\begin{array}{c}\text { Group A } \\
\text { Non SBP } \\
\text { ( N = 40) }\end{array}$ & $\begin{array}{c}\text { Group B } \\
\text { SBP } \\
(\mathbf{N = 4 0 )}\end{array}$ & P. Value \\
\hline Vital signs: & $101.9 \pm 14.8$ & $96 \pm 9.1$ & \\
1-systolic BP & $65.5 \pm 10.4$ & $64.8 \pm 5.9$ & 0.03 \\
2-diastolic BP & $37.5 \pm 0.8$ & $37.9 \pm 0.8$ & 0.7 \\
3-Temperature & $17.6 \pm 2.3$ & $17.3 \pm 2.9$ & 0.05 \\
4-Respiratory rate & $24(60 \%)$ & & 0.6 \\
\hline General examination: & $40(100 \%)$ & $40(65 \%)$ & 0.6 \\
1-Jaundice & $21(52.5)$ & $30(75 \%)$ & NA \\
2-lower limb edema & $20(50 \%)$ & $17(42.5 \%)$ & 0.4 \\
3-disorientation & $19(47.5 \%)$ & $14(35 \%)$ & 0.5 \\
4-Flabbing tremor & & \\
5-Hepatic encephalopathy & \multicolumn{2}{|c}{} \\
\hline
\end{tabular}

Table (6): Comparison between group A (Non SBP) and group B (SBP) regarding initial laboratory data

\begin{tabular}{|c|c|c|c|}
\hline Parameters & $\begin{array}{c}\text { Group A } \\
\text { Non SBP } \\
(\mathbf{N}=\mathbf{4 0})\end{array}$ & $\begin{array}{c}\text { Group B } \\
\text { SBP } \\
(\mathbf{N}=\mathbf{4 0})\end{array}$ & P. Value \\
\hline Hemoglobin (g/dl) & $9.5 \pm 0.9$ & $9.6 \pm 0.9$ & 0.8 \\
\hline $\mathrm{WBC} \times 1000 / \mathrm{mm}^{3}$ & $8.7 \pm 4.1$ & $8.7 \pm 3.4$ & 0.9 \\
\hline Platelet $\times 1000 / \mathrm{mm}^{3}$ & $83.83 \pm 29.03$ & $93.5 \pm 23.73$ & 0.12 \\
\hline Prothrombin time (second) & $16.2 \pm 1.5$ & $16.6 \pm 2$ & 0.4 \\
\hline INR & $1.6 \pm 0.2$ & $1.6 \pm 0.3$ & 0.3 \\
\hline ALT (IULL) & $50.7 \pm 21.2$ & $52.1 \pm 16.3$ & 0.7 \\
\hline AST (IUlL) & $58 \pm 21$ & $53.6 \pm 17.8$ & 0.3 \\
\hline Albumin (g/dl) & $2.1 \pm 0.4$ & $2.1 \pm 0.3$ & 0.7 \\
\hline Bilirubin Total (mg/dl) & $3.5 \pm 1.6$ & $3.8 \pm 1.7$ & 0.5 \\
\hline Bilirubin Direct (mg/dl) & $2.3 \pm 1.2$ & $2.4 \pm 1.2$ & 0.6 \\
\hline Urea $(\mathrm{mg} / \mathrm{dl})$ & $73.3 \pm 35.5$ & $73 \pm 20$ & 0.9 \\
\hline Creatinine $(\mathrm{mg} / \mathrm{dl})$ & $1.6 \pm 0.6$ & $1.8 \pm 0.6$ & 0.07 \\
\hline
\end{tabular}

Table (7): Comparison between group A (Non SBP) and group $\mathrm{B}(\mathrm{SBP})$ regarding ascitic fluid analysis

\begin{tabular}{|l|c|c|c|}
\hline \multicolumn{1}{|c|}{ Parameters } & $\begin{array}{c}\text { Group A } \\
\text { Non SBP } \\
(\mathbf{N = 4 0})\end{array}$ & $\begin{array}{c}\text { Group B } \\
\text { SBP } \\
(\mathbf{n = 4 0})\end{array}$ & P value \\
\hline $\begin{array}{l}\text { Ascitic fluid protein (g/L) } \\
\text { Normal( 0.3-4.0g/dL) }\end{array}$ & $1.5 \pm 0.5$ & $1.3 \pm 0.4$ & 0.09 \\
\hline Ascitic fluid Glucose (mg/L) & $156.8 \pm 63$ & $146.9 \pm 49.3$ & 0.4 \\
\hline $\begin{array}{l}\text { Ascitic fluid LDH (IU/L) } \\
\text { Normal<400 IU/L }\end{array}$ & $185.3 \pm 64.9$ & $201.6 \pm 55.9$ & 0.2 \\
\hline
\end{tabular}


Table (8): Comparison between group A (Non SBP) and group B(SBP) regarding ascitic fluid granulocyte elastase

\begin{tabular}{|c|c|c|c|}
\hline Variable & $\begin{array}{c}\text { Group A } \\
(\text { mean } \pm \text { SD })\end{array}$ & $\begin{array}{c}\text { Group B } \\
(\text { Mean } \pm \text { SD }\end{array}$ & P value \\
\hline Ascitic fluid granulocyte elastase (ng) & $0.8 \pm 1.1$ & $4.1 \pm 2.8$ & $\leq 0.001$ \\
\hline
\end{tabular}

Table (9): Comparison between group A (Non SBP) and group B(SBP) regarding Child-TurcottePugh classification

\begin{tabular}{|l|c|c|}
\hline \multicolumn{1}{|c|}{$\begin{array}{c}\text { Child Turcotte Pugh } \\
\text { Score }\end{array}$} & $\begin{array}{c}\text { Group A } \\
\text { Non-SBP patients (N=40) }\end{array}$ & $\begin{array}{c}\text { Group B } \\
\text { SBP patients } \\
(\mathbf{n = 4 0 )}\end{array}$ \\
\hline Child(A) & $0(0 \%)$ & $0(0 \%)$ \\
\hline Child(B) & $14(35 \%)$ & $5(12.5 \%)$ \\
\hline Child(C) & $26(65 \%)$ & $35(87.5 \%)$ \\
\hline
\end{tabular}

Table (10): Comparison between group A (Non SBP) and group B(SBP) regarding ascitic fluid WBCS counts and differential

\begin{tabular}{|l|c|c|c|}
\hline Variable & $\begin{array}{c}\text { Group A } \\
\text { Non-SBP patients } \\
(\mathbf{N = 4 0 )}\end{array}$ & $\begin{array}{c}\text { Group B } \\
\text { SBP patients } \\
(\mathbf{n = 4 0 )}\end{array}$ & P value \\
\hline Ascitic fluid TLC & $95.5 \pm 50.4$ & $2300.3 \pm 2157.8$ & $\leq 0.001$ \\
\hline Ascitic fluid PMN & $76.3 \pm 39.8$ & $1671.2 \pm 1096.5$ & $\leq 0.001$ \\
\hline
\end{tabular}

Table (11): Comparison between group A (Non SBP) and group B(SBP) regarding ascitic fluid WBCS counts and granulocyte elastase

\begin{tabular}{|l|cc|cc|c|}
\hline \multicolumn{1}{|c|}{ Variable } & \multicolumn{2}{|c|}{$\begin{array}{c}\text { Group A } \\
\text { Non-SBP patients } \\
(\mathbf{N = 4 0})\end{array}$} & \multicolumn{2}{c|}{$\begin{array}{c}\text { Group B } \\
\text { SBP patients } \\
(\mathbf{n = 4 0})\end{array}$} & P value \\
\hline Ascitic fluid PMN > 250 & 0 & 0 & 40 & 100.0 & $\leq 0.001$ \\
\hline $\begin{array}{l}\text { Ascitic fluid granulocyte } \\
\text { elastase }>\mathbf{0 . 8 8}\end{array}$ & 2 & 5 & 40 & 100.0 & $\leq 0.001$ \\
\hline
\end{tabular}




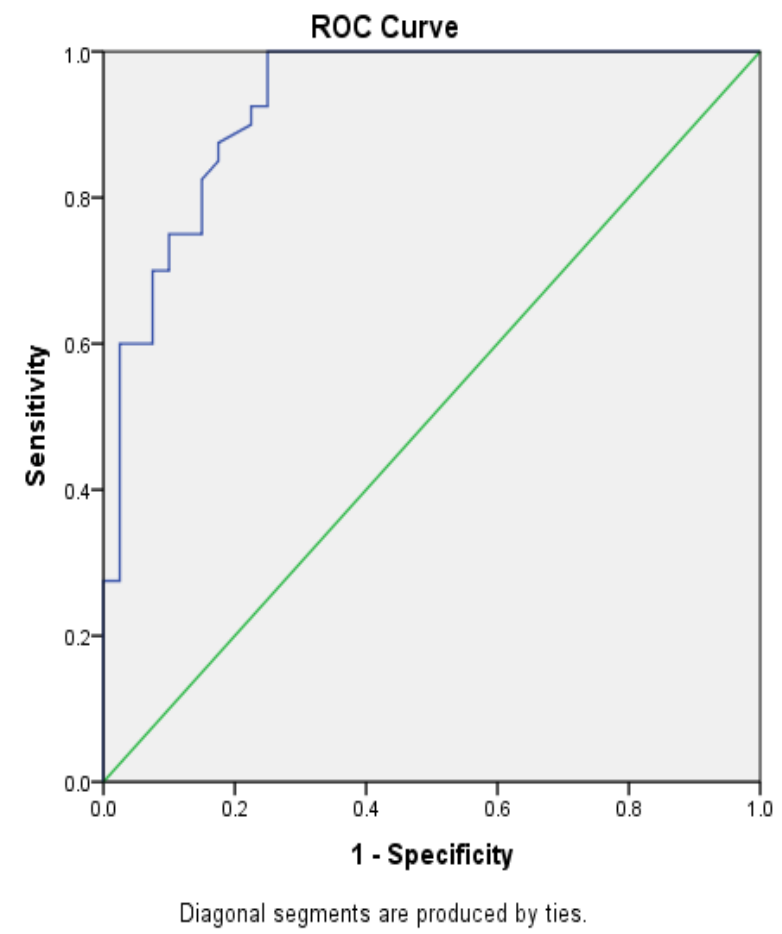

Figure (1): ROC curve for diagnosis of SBP by ascetic fluid granulocyte elastase by ELISA test

\section{DISCUSSION}

Ascites is the most common complication in patients with decompensated cirrhosis. Approximately $50 \%$ of patients with compensated cirrhosis will develop ascites over a 10-year period [15].

The most common infections in decompensated cirrhotic patients are cases of spontaneous bacterial peritonitis (SBP), which accounts for $40 \%-70 \%$ of cases, followed by urinary tract infections, pneumonia and cellulitis [16].

In this cross sectional comparative study which conducted on 80 patients with cirrhotic ascites, there was no statistical significant difference regarding gender and this in agree with study performed by Puri et al. [17] who reported that gender had no effect on incidence of SBP. Also the studies done by Chang et al.; Amany et al. and Nouh et al. [18-20] had found no statistical significant relation between SBP and gender. This result was not in agreement with the study done by Ageely et al. [21] included 115 cirrhotic ascitic patients, 46 of them had SBP who stated that SBP was frequent in males but was not influenced by the severity of liver disease or age. In this study mean age of patients in group $A$ (58.3 \pm 8.3$)$ and mean age of patients in group B $(55.8 \pm 7.5)$ without statistically significant difference.
Puri et al.; Chan et al.; Amany et al. and Nouh et al.[17-20] had founded that age seem to have no effect on the incidence of SBP.

In this study, seventy seven patients (96.3\%) of the studied population were $\mathrm{HCV}$ Ab positive and three patients $(3.7 \%)$ were HBsAg positive in agree with Amany et al.; Nouh et al. and Rizk et al. $[\mathbf{1 9 , 2 0 , 2 2}]$ demonstrated that HCV infection being the most frequent cause of chronic liver disease in Egypt. This was documented by Strickland [23] that Clinical studies showed 70\% to $90 \%$ of patients with chronic hepatitis, cirrhosis, or hepatocellular carcinoma had HCV infections.

In this study, abdominal pain and vomiting were the main clinical presentations in group B compared to group A. These results were found to be close to that reported by Chang et al. and Kaymakoglu et al. $[\mathbf{1 8 , 2 4}]$ they stated that abdominal pain and fever are the most characteristic symptoms in patients with spontaneous ascitic fluid infection.

Abdominal pain was detected in $75 \%$ of SBP patients. This result was close to the study done by Wallersted et al. and Bibi et al. [25,26] demonstrated that abdominal pain was detected in $70 \%, 68.5 \%$ of SBP cases respectively and also was close to the study done by Badawy et al. [27] who eilicited abdominal pain in $80.2 \%$ and $84.2 \%$ of two groups of SBP cases. On the other 
hand study performed by Rizk et al. and Ibrahim et al. [22,28] eilicited abdominal pain in $43 \%$ and $55.7 \%$ of SBP cases respectively.

In this study, hypotension and elevated temperature had statistically significant association with SBP group. These results were close to that reported by Zalam et al. [29] who stated that fever was detected in $75 \%$ of SBP cases with statistically significant association with SBP. On the other hand study performed by Bibi et al. [26] eilicited fever in $52.6 \%$ of SBP cases without statistical significant difference.

In this study, hepatic encephalopathy was detected in $35 \%$ of SBP and $47.5 \%$ of non SBP cases with statistically insignificant difference. These results were close to that reported by Wallersted et al. and Bibi et al. and Nobre et al. $[\mathbf{2 5 , 2 6 , 3 0 ]}$ who stated that hepatic encephalopathy was detected in $20 \%, 24.5 \%$ and $28.9 \%$ of SBP cases respectively. These results conflict the fact that the presence of hepatic encephalopathy in the course of liver cirrhosis is a marker of severe hepatic dysfunction that correlates with high prevalence of bacterial infections most commonly SBP [31]. This can be explained by selection bias of the two groups.

On the contrary, these results were against to that reported by Zalam et al.; Llovet et al. and Elsaaed et al. $[29,32,33]$ who stated that hepatic encephalopathy was detected in $40 \%, 40.4 \%$ and $50 \%$ of SBP cases respectively with high statistical significance. This can be explained by development of portosystemic encephalopathy indicates decompensated liver disease and therefore, other features of decompensation, such as varices, ascites, and portal hypertension.

In this study we had found that mean hemoglobin was $(9.5 \pm 0.9)$, mean total leucocytic count was $(8.7 \pm 4.1) \times 1000 / \mathrm{cm}^{3}$, mean platelet count was $(83.8 \pm 29.03) \times 1000 / \mathrm{cm}^{3}$ and mean prothrombin time was $(16.2 \pm 1.5)$ second in group A while mean hemoglobin was $(9.6 \pm 0.9)$, mean total leucocytic count was $(8.7 \pm 3.4) \times 1000 / \mathrm{cm}^{3}$, mean Platelet count was $(93.5 \pm 23.7) \times 1000 / \mathrm{cm}^{3}$ and mean prothrombin time (16.6 \pm 2$)$ second in group $\mathrm{B}$ without statistical significant difference.

This go on line with study done by Nouh et al.; Zalam et al. and Elsaaed et al. [20,29,33] demonstrated that no statistical significant differences were detected as regard TLC among both patient groups.

On the contrary, these results were against to the study done by Amany et al.; Rizk et al.;
Rodriguez-Ramos et al.; Syed et al. and Lutz et al. $[19,22,34-36]$ reported that there was statistically significant high serum total leucocytic count in SBP group. This could be explained by that bacterial translocation to mesenteric lymph node had important immunological function associated with local/systemic inflammatory response leading to peripheral leukocytosis [37].

The present study had showed that decrease $\mathrm{Hb}$ $\%$, platelet count and prolonged prothrombin time in comparison to non infected cases, this was in agreement with Gschwantler et al. and Kawasaki et al. [38,39] who stated that in patients with CLD, a sort of pancytopenia would be expected due to increased blood sequestration in the spleen and to low thrombopoietin levels.

In this study, there was no statistical significant difference between both groups regarding serum alanine transaminase, serum aspartate transaminase, serum albumin and bilirubin (total \& direct). This in accordance with Nouh et al.; Rizk et al. and Zalam et al. [20,22,29] who reported no statistical significant differences were detected as regard liver function test among both groups.

On the contrary, Amany et al. and Elsaaed et al. $[19,33]$ reported statistically significant lower serum albumin level in SBP group. And also ElGendy et al. [40] stated statistically significant elevated serum bilirubin and prolonged prothrombin time in SBP group.

In this study regarding the kidney function test, there was no statistical significant difference and this agree with Amany et al.; Nouh et al. and Zalam et al. $[19,20,29]$ who reported no statistical significant difference comparing both groups as regards kidney function tests.

These results were coinciding with the study done by Rizk et al.; Lutz et al.; Ruiz Del Arbol et al. and Gill et al. $[\mathbf{2 2 , 3 6 , 4 1 , 4 2 ]}$ found that patients with SBP frequently develop a rapidly progressive impairment in systemic hemodynamics, leading to severe renal and hepatic failure, aggravation of portal hypertension, encephalopathy, and death. This occurs despite rapid resolution of infection and is associated with an extremely poor prognosis. Also the study performed by Follo et al. [43] stated that one third of patients with SBP develop renal impairment and it is common in patients with severely impaired liver functions. It is not worthy that hepatorenal syndrome is the extreme expression of this circulatory dysfunction [44]. 
In this study, SBP was more common in advanced Child-Pugh class $C(87.5 \%)$ of patient in group B (SBP) compared with (65\%) of patients in group A (Non SBP) meaning that the severity of the liver disease is probably an important risk factor for the development of SBP [45]. This was close to Quenzer [46] who reported that about $70 \%$ of the patients who develops SBP are in Child C class, with the remainder being class $\mathrm{B}$.

By ascitic fluid analysis in studied groups, the mean ascitic fluid protein was $(1.5 \pm 0.5 \mathrm{~g} / \mathrm{dl})$, mean ascitic fluid glucose was $(156.8 \pm 63 \mathrm{mg} / \mathrm{l})$ and mean ascitic fluid lactate dehydrogenase [LDH] was $(185.3 \pm 64.9 \mathrm{IU} / \mathrm{L})$ in group A. While in group B mean ascitic fluid protein was (1.3 \pm $0.4 \mathrm{~g} / \mathrm{dl}$ ), mean ascitic fluid glucose was $(146.9 \pm 49.3 \mathrm{mg} / \mathrm{l})$ and mean ascitic fluid LDH was $(201.6 \pm 55.9 \mathrm{IU} / \mathrm{L})$.

By comparison between studied groups, there was no statistical significant difference regarding ascitic fluid analysis $(\mathrm{P}>0.05)$, and this in accordance with Zalam et al. and Elsaaed et al. $[29,33]$ who reported that there was no statistical significant difference regarding ascitic fluid total protein, glucose and LDH levels between both groups. And also Bibi et al. [26] reported that there was no statistical significant difference regarding ascitic fluid total protein, glucose.

This result on disagreement with study performed by Amany et al. [19] stated statistical significant low ascitic fluid total protein, glucose and elevated LDH in SBP group. And also with study done by Abbass et al. [47] reported statistical significant low ascitic fluid albumin in SBP group while other parameters are statistically insignificant.

This result could be explained as both groups showed advanced liver disease so both have low proteins. Thus a follow up paracentesis is recommended as it may detect development of SBP being a high risk group. It is to be noted that, in contrast to other infected body fluids, ascitic fluid during SBP exhibited neither a rise in protein concentration nor a drop in absolute glucose concentration [48]. These results were contradictory to Sheer and Runyon [49] who reported that ascitic fluid total proteins were lower in patients with SBP than patients with sterile cirrhotic ascites and to Runyon [50] who stated that patients with low ascitic fluid total proteins $(<1 \mathrm{~g} / \mathrm{dl})$ have to receive an antibiotic chemoprophylaxis as they are more prone to recurrence of SBP than those with high ascitic fluid total protein content $(>1 \mathrm{~g} / \mathrm{dl})$. Moreover, low ascitic fluid protein level $<\mathrm{g} / \mathrm{dl}$ considered to be the most important predisposing factor for developing the first episode of SBP [51] this was confirmed by Guarner et al. [52] who observed that about one fourth of patients with ascitic fluid protein levels less than $1 \mathrm{~g} / \mathrm{dl}$ developed SBP during a 3-year follow-up compared to only $4 \%$ of patients with higher levels.

By comparison between group A and group B regarding ascitic fluid granulocyte elastase. There was high statistically significant association between $\mathrm{SBP}$ and granulocyte elastase (P value $<0.05)$.

This result was in agreement with the study performed by [9] reported GE level was statistically significant higher in both ascitic fluid and plasma of SBP group than in non-SBP group at the time of diagnosis.

Also this result go on line with study done by Yamazaki et al. [53] stated that ascitic fluid GE levels were significantly higher in SBP group as detected by three different methods (latex immuonoassy, ELISA and reagent strip).

As regards this study, we found that cutoff of ascitic fluid (GE) for diagnosis of SBP at 0.88 $\mathrm{ng} / \mathrm{ml}$ had sensitivity $100 \%$, specificity $75 \%$ and these coincides with Yamazaki et al.s [53] who reported that cut-off diagnostic value for SBP for ascitic fluid GE latex immunoassy at $49.5 \mathrm{ng} / \mathrm{ml}$ had $85.7 \%$ sensitivity and $97.7 \%$ specificty. This difference may be due to small number of SBP patients in this study which include 58 cirrhotic ascitic patients, 12 one of them only having SBP.

In conclusion, Diagnosis of SBP on clinical basis is difficult as there is extremely variable clinical presentaions. fever; hypotension and abdominal pain were more common in SBP group. Granulocyte elastase (GE) is increased in cases of spontaneous bacterial peritonitis (SBP) with cutoff value of ascitic fluid (GE) for diagnosis of SBP was at $>0.88 \mathrm{ng} / \mathrm{mL}$ had $100 \%$ sensitivity, $75 \%$ specificity, $80 \%$ positive predictive value, $100 \%$ negative predictive value with $87.5 \%$ accuracy.

\section{Acknowledgment}

The authors would thank Dr. Mohamed Abed ElAziz Metwally, Dr. Mohammad El-Sayed ElShewi and Dr. Jehan Hassan Sabry who helped in conducting this study. And staff of the Tropical Medicine Department, and to the laboratory technicians, for their valuable efforts. 
Ethical approval: Approved.

Funding: None.

Conflict of interest: Authors declare no conflict of interest related to this article.

\section{REFERENCES}

1- D’Amico, G; Garcia-Tsao, G., Pagliaro, L. Natural history and prognostic indicators of survival in cirrhosis: a systematic review of 118 studies. $J$ Hepatol 2006; 44: 217-231.

2- Friedman SL. Preface. Hepatic fibrosis: pathogenesis, diagnosis, and emerging therapies. Clin Liver Dis. Nov 2008;12(4):xiii-xiv.

3- Ripoll ,C; Groszmann, R; Garcia-Tsao, G ;Grace, $\mathrm{N}$; Burroughs, A; Planas, Ret al. Hepatic venous pressure gradient predicts clinical decompensation in patients with compensated cirrhosis. Gastroenterology. 2007;133:481-488.

4- Koulaouzidis, A. Diagnosis of spontaneous bacterial peritonitis: an update on leucocyte esterase reagent strips. World J Gastroenterol 2011; 17(9):1091-4.

5- Cereto, F; Genescà ,J and Segura, R. Validation of automated blood cell counters for the diagnosis of spontaneous bacterial peritonitis. Am J Gastroenterol 2004; 99: 1400 .

6- Nousbaum, JB; Cadranel, JF; Nahon, P; Khac, EN; Moreau, R; Thévenot, $\mathrm{T}$ et al. Diagnostic accuracy of the Multistix 8 SG reagent strip in diagnosis of spontaneous bacterial peritonitis. Hepatology 2007; 45(5), 1275-1281.

7- Parsi, MA; Saadeh, SN; Zein, NN; Davis, GL; Lopez, R; Boone, J et al. Ascitic fluid lactoferrin for diagnosis of spontaneous bacterial peritonitis. Gastroenterology 2008; 135(3), 803-807.

8- Burri, E; Schulte, F; Muser, J; Meier, R and Beglinger, C. Measurement of calprotectin in ascitic fluid to identify elevated polymorphonuclear cell count. World J Gastroenterol 2013;. Apr 7; 19(13): 2028-3.

9- Casafont, F; Rivero, M; Fernandez, MD; Crespo, J; Fabrega, E; Sanchez, E et al. Granulocyte elastase in cirrhotic patients with spontaneous bacterial peritonitis. Dig Dis Sci 1999; 44(10), 1985-1989.

10- Heidelbaugh, JJ and Bruderly, M. Cirrhosis and chronic liver failure: part I. Diagnosis and evaluation. Am Fam Physician 2006; 74(5), 75662.

11- Krastev, N; Djurkov, V; Murdjeva, M; Akrabova, P; Karparova, T; Penkov, V et al. Diagnosis of spontaneous and secondary bacterial peritonitis in patients with hepatic cirrhosis and ascites. Khirurgiia 2013; (3), 20-25.
12- Dufour, DR; Lott, JA; Nolte, FS; Gretch, DR; Koff, RS, Seeff, LB. Diagnosis and monitoring of hepatic injury. II. Recommendations for use of laboratory tests in screening, diagnosis and monitoring. Clin Chem. 2000; 46:2050-2068.

13- Liu, C; Chen, T; Lin, J; Chen, H; Chen ,J; Lin, S et al. Evaluation of the performance of four methods for detection of he patitis B surface antigen and their application for testing 116,455 specimens. J Virol Methods 2014; 196, 174-178.

14- Colin, C; Lanoir, D; Touzet, S; Meyaud Kraemer, L; Bailly, F, Trepo, C. Sensitivity and specificity of third- generation hepatitis $\mathrm{C}$ virus antibody detection assays: an analysis of the literature. $J$ Viral Hepat 2001; 8(2), 87-95.

15- Saadeh ,S, Davis, GL. Management of ascites in patients with end- stage liver disease. Rev Gastroenterol Disord 2004;4(4):175-85.

16- Shalimar, Acharya SK. Difficult to treat spontaneous bacterial peritonitis. Trop Gastroenterol 2003; 34:7-13.

17- Puri AS; Puri, J; Ghoshal, UC; Sharma, BC; Saraswat ,VA; Ayyagari ,A et al. Frequency, microbial spectrum and outcome of spontaneous bacterial peritonitis in north India. Indian $J$ Gastroenterol 1996;.15(3):86-9.

18- Chang, CS; Chen, GH, Lien, HC. Small intestine dysmotility and bacterial overgrowth in cirrhotic patients with spontaneous bacterial peritonitis. Hepatology 1998; 28: 1187.

19- Amany ,TK; Eman, NO, Rasha ,YS. Role of ascitic fluid $\mathrm{C} 3$ in spontaneous bacterial peritonitis. The Egyptian Journal of Medical Human Genetics 2012; 13, 81-85.

20- Nouh, MAED; El-Deeb, GS; El-Aziz, MA, Ibrahim, EH. Study of serum and ascitic fluid nitric oxide levels in cirrhotic patients with or without spontaneous bacterial peritonitis. AAMJ 2014; 12(4).

21- Ageely H; Ayoola EA; Al-Hazim M, Gadour M. Spontaneous bacterial peritonitis in Saudi Arabian patients with non alcoholic liver cirrhosis. Hepatogastroenterology 2000; 47 (36): $1649-53$.

22- Rizk, E; Elzehery, R; Zakaria, S; Abdel-Razik, A and Elhammady, D. Ascitic Fluid Calprotectin and Serum C-Reactive Protein as Diagnostic Markers for Spontaneous Bacterial Peritonitis. Afro-Egypt J Infect End Dis 2014; 4(3):117-125.

23- Strickland, GT. Liver disease in Egypt: hepatitis C superseded schistosomiasis as a result of iatrogenic and biological factors. Hepatology 2006, 43(5), 915-922. 
24- Kaymakoglu, S; Eraksoy, H; Ökten, A; Demir, K; Çalangu, S; Çakaloglu, Y et al. Spontaneous ascitic infection in different cirrhotic groups: prevalence, risk factors and the efficacy of cefotaxime therapy. Euro $J$ Gastroenterol Hepatol 1997; 9(1), 71-76.

25- Wallersted ,TS; Olsson, R; Simern, M; Broomé U; Wahlin, S; Lööf, L et al. Abdominal tenderness in ascites patients indicates spontaneous bacterial peritonitis. Eur. J. Internal medicine 2007; 18: 44-47.

26- Bibi, S; Ahmed, W; Arif, A; Khan, F, Alam, SE. Clinical, Laboratory and Bacterial Profile of Spontaneous Bacterial Peritonitis in Chronic Liver Disease Patients. Journal of the College of Physicians and Surgeons-Pakistan: JCPSP 2015; 25(2), 95-99.

27- Badawy, AA; Zaher, TI; Sharaf, SM; Emara, MH; Shaheen, NE, Aly, TF. Effect of alternative antibiotics in treatment of cefotaxime resistant spontaneous bacterial peritonitis. World $J$ Gastroenterol 2013; 19(8), 1271.

28- Ibrahim, AM; Mansour, MA; Mansour, SA, Hamed, EF. Serum Complement 3 Level and Culture Positivity As Predictors Of Spontaneous Bacterial Peritonitis Recurrence In Egyptian Cirrhotic Patients. International Journal 2014; 2(9), 816-824.

29- Zalam, SS; Moustafa, H, Samy, AKOS. The Values of Serum and Ascetic Fluid Tumor Necrosis Factor-Alpha in Patients with SBP. Cairo medical Journal 2010;41:491-501.

30-Nobre, SR; Cabral, JE; Gomes, JJ, Leitão, MC. Inhospital mortality in spontaneous bacterial peritonitis: a new predictive model. Eur. J. Gastroenterol Hepatol. 2008;20:1176-1181.

31- Edna Strauss, MD; Maria , F, Ribeiro, MD. Bacterial infections associated with hepatic encephalopathy: Prevalence and outcome. Ann Hepatol 2003;2(1): 41-45.

32- Llovet, J; Moitinho, E; Sala; Bataller, R; Rodríguez-Iglesias, PM; Castells, A. Prevelance and prognostic value of hepato cellular carcinoma in cirrhotic patients presenting with spontaneous bacterial peritonitis. J. Hepatology 2000; 33: 42329.

33- Elsaaed, NH, Galal-ElDin, MM, Gafar, MM, Fouad, SA. Prevalence and Characteristics of Spontaneous Bacterial Peritonitis in Hospitalized Patients with Ascites due to Liver Cirrhosis. Scientific Medical Journal (Cairo), 2009.
34- Rodriguez-Ramos, C; Galan, F; Diaz, F; Elvira, J; Martín-Herrera, L, Girón-González, JA. Expression of proinflammatory cytokines and their inhibitors during the coureof spontaneous bacterial peritonitis. Dig Dis Sci 2001;46 (8):1668 - 1676.

35- Syed VA; Ansari, JA; Karki P; Regmi M, Khanal B. Spontaneous bacterial peritonitis (SBP) in cirrhotic ascites: A prospective study in a tertiary care hospital Nepal. Kathmandu Univ Med J (KUMJ). 2007;5(1):48-59.

36- Lutz, P; Pfarr, K; Nischalke, HD; Krämer, B; Goeser, F; Glässner, $A$ et al. The ratio of calprotectin to total protein as a diagnostic and prognostic marker for spontaneous bacterial peritonitis in patients with liver cirrhosis and ascites. Clin Chem Lab Med. 2015;53(12):2031-9

37- Wiest, R and Garcia- Tsao, G. Bacterial translocation (BT) in cirrhosis. Hepatology 2005; 41(3), 422-433.

38- Gschwantler, M; Vavrik, J; Gebauer, A; Kriwanek, S; Schrutka-Kölbl, C; Fleischer, J et al. Course of platelet counts in cirrhotic patients after implantation of a transjugular intrahepatic portosystemic shunt-a prospective, controlled study. J Hepatol 1999; 30(2), 254-259.

39- Kawasaki, T; Takeshita, A; Souda, K; Kobayashi, Y; Kikuyama, M; Suzuki, F et al. Serum thrombopoietin levels in patients with chronic hepatitis and liver cirrhosis. Am. J. Gastroenterol. 1999; 94: 1918-1922.

40- El-Gendy, NA; Tawfeek, NA; Saleh, RA; Radwan, EE; Ahmad, EE, Mohammed, RA Diagnosis of spontaneous bacterial peritonitis. The Egyptian Journal of Internal Medicine 2014;26(2), 53.

41- Ruiz Del Arbol, L, Urman, J, Fernandez, J, González ,M; Navasa, M; Monescillo, A et al. Systemic, renal and hepatic hemodynamic derangement in cirrhotic patients with spontaneous bacterial peritonitis. Hepatology 200338(5):1210-1218.

42- Gill, AS; Singh, A; Matreja, PS; Mahajan, RSC and Chhina, DK. Spontaneous Bacterial Peritonitis in AlcoholicCirrhosis: An Indian Perspective. Euroasian Journal of HepatoGastroenterology 2012; 2(1), 14-19.

43- Follo, A, Llovet, JM, Navasa, M, Planas, R; Forns, X; Francitorra, A et al. Renal impairment after spontaneous bacterial peritonitis in cirrhosis: Incidence, clinical course, predictive factors and prognosis. Hepatology 1994; 20(6):1495-1501. 
44- Dagher, L and Moore, K. The hepatorenal syndrome. Gut2001;49(5):729-737.

45- Mustafa, G; Khan, M; Alam, K; Rahman, S; Ahmad, N; Alam, S et al. Study on ascitic fluid complement 3 level in cirrhotic patients with spontaneous bacterial peritonitis and without spontaneous bacterial peritonitis. Hepatogastroenterology 2007; 54(79): 1905-190721.

46- Quenzer RW. Primary peritonitis: spontaneous bacterial peritonitis. Treatment Options. Infect Dis 2001; 3: 359-365.

47- Abbass, S; Shebl, N; El Sharnooby, A; Hindawy, G; Aldin, M M, Younis , F. Ascetic Fluid and Serum Procalcitonin Levels as a Diagnostic and Prognostic Markers in Cases of Spontaneous Bacterial Peritonitis. Egyptian Journal of Medical Microbiology 2011; 20(1).

48- Runyon, BA. Management of adult patients with ascites due to cirrhosis. Hepatology 2004; 39(3): 841-856.

49- Sheer, TA, Runyon, BA. Spontaneous bacterial peritonitis. Dig Dis 2005; 23(1):3946.

50- Runyon, BA. Early events in spontaneous bacterial perionitis. Gut 2004; 53: 782-784.
51- Andreu, M; Sola, R; Sitges Serra, A; Alia ,C; Gallen, M ; Vila, M C et al. Risk factors for spontaneous bacterial peritonitis in cirrhotic patients with ascites. Gastroenterology 1993; 104(4):1133-1138.

52- Guarner, C; Sola, R; Soriano, G ;Andreu, M; Novella ,MT ; Vila, M C et al. Risk of a first community-acquired spontaneous bacterial peritonitis in cirrhotics with low ascitic fluid protein levels. Gastroenterology 1999, 117(2):414-419.

53- Yamazaki; Sano; Kuramoto; Yoshiji; Uemura; Fukui, H et al. Rapid detection of spontaneous bacterial peritonitis by granulocyte elastase latex immunoassay and reagent strip. Rinsho byori. The Japanese journal of clinical pathology 2011; 59(6), 549-558.

Peer reviewer: Sherif Galal ,Assistant Professor of Tropical Medicine and Hepatogastroenterology, Faculty of Medicine, Zagazig University, Egypt. Editor: Mohamad Emara, Assistant Professor of Tropical Medicine and Hepatogastroenterology, Faculty of Medicine, Zagazig University, Egypt 